\title{
Comparative Study of Strength and Corrosion Resistant Properties of Plain and Blended Cement Concrete Types
}

\author{
Velu Saraswathy, ${ }^{1,2}$ Subbiah Karthick, ${ }^{1,3}$ Han Seung Lee, ${ }^{1}$ \\ Seung-Jun Kwon, ${ }^{4}$ and Hyun-Min Yang ${ }^{1}$ \\ ${ }^{1}$ Department of Architectural Engineering, Hanyang University, 1271 Sa 3-dong, Sangrok-gu, Ansan 426791, Republic of Korea \\ ${ }^{2}$ Corrosion and Materials Protection Division, CSIR-Central Electrochemical Research Institute, Karaikudi, Tamil Nadu 630003, India \\ ${ }^{3} P G$ and Research Department of Chemistry, Alagappa Government Arts College, Karaikudi, Tamil Nadu 630003, India \\ ${ }^{4}$ Department of Civil Engineering, Hannam University, Daejeon 306-791, Republic of Korea
}

Correspondence should be addressed to Seung-Jun Kwon; jjuni98@hannam.ac.kr

Received 29 May 2017; Accepted 31 July 2017; Published 4 October 2017

Academic Editor: Michael J. Schütze

Copyright (c) 2017 Velu Saraswathy et al. This is an open access article distributed under the Creative Commons Attribution License, which permits unrestricted use, distribution, and reproduction in any medium, provided the original work is properly cited.

\begin{abstract}
The relative performances of mechanical, permeability, and corrosion resistance properties of different concrete types were compared. Concrete types were made from ordinary Portland cement (OPC), Portland pozzolana cement (PPC), and Portland slag cement (PSC). Compressive strength test, effective porosity test, coefficient of water absorption, short-term accelerated impressed voltage test, and rapid chloride permeability test (RCPT) were conducted on M30 and M40 grades of concrete designed with OPC, PPC, and PSC cements for 28- and 90-day cured concrete types. Long-term studies such as microcell and electrochemical evaluation were carried out to understand the corrosion behaviour of rebar embedded in different concrete types. Better corrosion resistant properties were observed for PSC concrete by showing a minimum current flow, lowest free chloride contents, and lesser porosity. Besides, PSC concrete has shown less coefficient of water absorption, chloride diffusion coefficient (CDC), and lower corrosion rate and thereby the time taken for initiation of crack extended.
\end{abstract}

\section{Introduction}

Reinforced concrete is protected from corrosion due to the high alkalinity existing in the concrete environment and the cover concrete which acts as a protective barrier to the access of chloride ions. Apart from this, reinforced concrete structures when exposed to severe marine environments lead to the premature failure of the structures [1]. Corrosion of embedded steel in concrete is one of the major causes of premature deterioration of concrete structures which affects the service life of the important structures in the chloride prone environment [2]. Therefore, the chloride permeability plays a significant role in determining the service life of the major infrastructures [3]. Due to the heterogeneous nature of the concrete, chloride ions enter the pores and attack the embedded steel in concrete causing cracking and spalling of the cover concrete portion and exposing the steel reinforcement when it is exposed to the marine environment [4].
Hence, to enhance the durability of the structures, waste materials like fly ash, rice husk ash, slag, and other pozzolanic materials are being used in the construction industry, not only from the durability point of view, but also to reduce the greenhouse gas emission and to save the environment [5]. The use of supplementary cementitious materials (SCM) and their effectiveness in making the blended cement concrete are well debated in the literature [6-12]. The composition of SCM may vary from source to source from which they are collected, because the nature of the source depends upon the raw materials used for making the manufacturing process and the geographical conditions [13].

Curing plays a major role in affecting the strength and permeability characteristics of the concrete structures. Mainly while using supplementary cementitious materials, care should be taken for continuous curing of the structures in the initial stages since hydration reactions are slow in using pozzolanic materials. The other factors which influence the 
strength characteristics are fineness modulus, water-cement ratio (w/c), chemical composition, and so on [14, 15]. Many researchers have discussed the different types of curing, pore structure refinement, and permeability characteristics of blended cements by using fly ash, slag, silica fume, and so on [16-19]. The results indicated that blended cement with longer duration has shown strength and other properties equal to those of ordinary Portland cement. It is also reported that blended cements enhanced the workability, durability, and mechanical properties of the concrete [20-24]. So far, the studies have focused on the particular aspect of corrosion like permeability, pore structure, chloride ingress, or physical and chemical characteristics by either short-term or long-term studies.

Hence, the aim of the present investigation is to evaluate the corrosion resistant properties of rich and lean mix concrete made from Portland pozzolana cement (PPC) and Portland slag cement (PSC) under accelerated and normal exposure conditions. The results were compared with ordinary Portland cement (OPC) concrete. Further, in this investigation, two curing periods, two grades of concrete, and two different exposure conditions, namely, normal and accelerated exposure conditions, were carried out. In addition to these, short-term and long-term tests, porosity and permeability studies, and mechanical and electrochemical studies were also carried out for plain and blended cements, and the results were presented in a detailed manner.

\section{Experimental}

2.1. Materials and Mix Proportions. Two mix proportions having characteristic compressive strength of 30 and 40 $\mathrm{MPa}$ concrete types were used for casting the concrete specimens. The details of concrete mix proportions are given in Table 1. Three cements, namely, 43 grade ordinary Portland cement conforming to IS:8112 [25] (equivalent to ASTMType I cement), Portland pozzolana cement conforming to IS:1489-Part-I [26], and Portland slag cement conforming to IS:455 [27], were used. Chemical composition of cements used is given in Table 2. Graded river sand passing through $1.18 \mathrm{~mm}$ sieve with a fineness modulus of 2.85 and a specific gravity of 2.55 was used as fine aggregate. Locally available well graded aggregates of normal size greater than $4.75 \mathrm{~mm}$ and less than $20 \mathrm{~mm}$ having a fineness modulus of 2.72 were used as coarse aggregates. The specific gravity of the fine aggregate used was 2.78 . Thermomechanically treated (TMT) rebar (Fe-415 grade) of $12 \mathrm{~mm}$ diameter conforming to IS:1786 [28] was used. Potable water was used for casting the concrete.

\subsection{Methods}

2.2.1. Compressive Strength. Compressive strength test was carried out in concrete cubes of size $150 \times 150 \times 150 \mathrm{~mm}$ using $1: 1.8: 3.69 \mathrm{mix}$ with w/c ratio of 0.55 (M30 grade) and $1: 1.18: 3.36$ with w/c ratio 0.45 (M40 grade) using OPC and blended cements (PPC and PSC). During casting, the moulds were mechanically vibrated. After 24 hours, the specimens

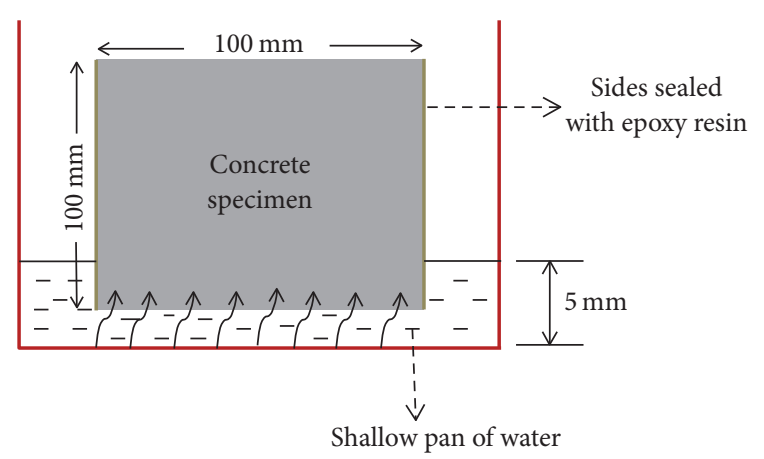

FIGURE 1: Schematic of coefficient of water absorption test.

were removed from the mould and subjected to water curing for 28 and 90 days. After a specified period of curing, the specimens were tested for compressive strength using AIMIL compression testing machine of $2000 \mathrm{kN}$ capacity at a rate of loading of $210 \mathrm{kN} / \mathrm{min}$. The tests were carried out on six specimens and the average compressive strength values were recorded for OPC, PPC, and PSC concrete types.

2.2.2. Effective Porosity Test. Percentage of water absorption is a measure of the pore volume or porosity in hardened concrete, which is occupied by water in saturated condition. Water absorption test was carried out as per ASTM C642-97 [29]. The effective porosity for OPC, PPC, and PSC concrete types is calculated as follows:

$$
\text { Effective porosity }(\%)=\frac{(B-A)}{V} \times 100,
$$

where $A$ is mass of oven dried sample in air, $B$ is saturated mass of the surface dry sample in air after immersion, and $V$ is bulk volume of the sample.

2.2.3. Coefficient of Water Absorption. Coefficient of water absorption is suggested as a measure of permeability of water. This is measured by the rate of uptake of water by dry concrete over a period of $1 \mathrm{~h}$. The concrete cube specimens of $100 \times$ $100 \times 100 \mathrm{~mm}$ were preconditioned by drying in an oven at $105^{\circ} \mathrm{C}$ for $48 \mathrm{hrs}$ until constant weight was reached and then allowed to cool in an airtight sealed container for 3 days. The sides of the concrete samples were coated with transparent epoxy resin to allow the flow of water in unidirection. Then the samples were kept in a vertical position partially immersed up to a depth of $5 \mathrm{~mm}$ at one end while the rest of the portions were kept exposed to the atmosphere as shown in Figure 1. The quantity of water absorbed during the first $60 \mathrm{~min}$ was calculated. Coefficients of water absorption values for OPC, PPC, and PSC concrete specimens after 28 and 90 days of moisture curing were determined using the formula [29]

$$
K_{a}=\left(\frac{Q}{A}\right)^{2} \times \frac{1}{t},
$$

where $K_{a}$ is the coefficient of water absorption $\left(\mathrm{m}^{2} \mathrm{~s}^{-1}\right), Q$ is the quantity of water absorbed $\left(\mathrm{m}^{3}\right)$ by the oven dry specimen 
TABLE 1: Details of concrete mix proportions.

\begin{tabular}{|c|c|c|c|c|c|c|}
\hline Grade & Type of cement & $\mathrm{W} / \mathrm{C}$ ratio & $\begin{array}{l}\text { Cement } \\
\left(\mathrm{kg} \mathrm{m}^{-3}\right)\end{array}$ & $\begin{array}{c}\text { Fine } \\
\text { aggregate } \\
\left(\mathrm{kg} \mathrm{m}^{-3}\right)\end{array}$ & $\begin{array}{c}\text { Coarse } \\
\text { aggregate } \\
\left(\mathrm{kg} \mathrm{m}^{-3}\right)\end{array}$ & $\begin{array}{c}\text { Water } \\
\left(\mathrm{kg} \mathrm{m}^{-3}\right)\end{array}$ \\
\hline \multirow{3}{*}{ M30 } & OPC & 0.55 & 338 & 607 & 1247 & 186 \\
\hline & PPC & 0.55 & 338 & 607 & 1247 & 186 \\
\hline & PSC & 0.55 & 338 & 607 & 1247 & 186 \\
\hline \multirow{3}{*}{ M40 } & OPC & 0.45 & 400 & 472 & 1247 & 180 \\
\hline & PPC & 0.45 & 400 & 472 & 1247 & 180 \\
\hline & PSC & 0.45 & 400 & 472 & 1247 & 180 \\
\hline
\end{tabular}

TABLE 2: Chemical composition of cements.

\begin{tabular}{lccc}
\hline Constituent & \multicolumn{3}{c}{ Weight/(\%) } \\
& OPC & PPC & PSC \\
\hline $\mathrm{SiO}_{2}$ & 21.0 & 32.0 & 31.0 \\
$\mathrm{Al}_{2} \mathrm{O}_{3}$ & 5.50 & 10.0 & 10.5 \\
$\mathrm{Fe}_{2} \mathrm{O}_{3}$ & 4.60 & 5.50 & 2.80 \\
$\mathrm{CaO}$ & 63.0 & 44.0 & 47.0 \\
$\mathrm{MgO}$ & 0.60 & 1.50 & 3.90 \\
$\mathrm{SO}_{3}$ & 2.60 & 2.60 & 2.60 \\
$\mathrm{LOI}$ & 2.70 & 4.40 & 2.70 \\
\hline
\end{tabular}

in time $(t), t$ is $3600 \mathrm{~s}$, and $A$ is the surface area $\left(\mathrm{m}^{2}\right)$ of concrete specimen through which water penetrates.

2.2.4. Impressed Voltage Test. Cylindrical concrete specimens of size $50 \mathrm{~mm}$ diameter and $100 \mathrm{~mm}$ height were cast using M30 and M40 grades of concrete types. Rebar types of $12 \mathrm{~mm}$ diameter and $100 \mathrm{~mm}$ height were embedded centrally into the concrete specimens. During casting, the moulds were mechanically vibrated. After $24 \mathrm{~h}$, the cylindrical concrete specimens were demoulded and cured for 28 and 90 days. Then the specimens were subjected to impressed voltage test. In this technique, the concrete specimens were immersed in $5 \% \mathrm{NaCl}$ solution and embedded steel in concrete is made as anode with respect to an external stainless steel electrode serving as the cathode by applying a constant positive potential of $12 \mathrm{~V}$ to the system from a DC source. The variation of current is recorded with time. For each specimen, the time taken for initial crack and the corresponding maximum anodic current flow was recorded [30].

At the end of the $12 \mathrm{~V}$ impressed voltage test, the embedded steel specimens were broken and the sections were open, cleaned in pickling solution (concentrated $\mathrm{HCl}$ containing $20 \mathrm{~g} / \mathrm{L}$ of stannous chloride and $15 \mathrm{~g} / \mathrm{L}$ of antimony trioxide), then cleaned in distilled water, dried, and weighed as per ASTM G1-03 [31]. From the initial weight, the loss in weight of embedded steel due to accelerated corrosion in OPC, PPC, and PSC concrete types was calculated. From the weight loss data, corrosion rate in mmpy was calculated using the following equation [2]:

$$
\text { Corrosion rate }=87.6 \times\left(\frac{W}{D \times A \times T}\right),
$$

where $W$ is the weight loss in milligram, $D$ is the density of the material used, $\mathrm{g} / \mathrm{cc}, A$ is the area of the specimen $\left(\mathrm{cm}^{2}\right)$, and $T$ is the duration of the test period in hours.

2.2.5. Rapid Chloride Ion Permeability Test (RCPT). The resistance to chloride ion penetration in terms of total charge that passed in coulombs through OPC and blended concrete specimens after 28 and 90 days of moisture curing was measured as per ASTM C1202-12 [32]. A concrete disc of size $100 \mathrm{~mm}$ diameter and $50 \mathrm{~mm}$ thickness was cast and allowed to cure for 28 and 90 days. Then the concrete specimens were subjected to the RCPT by impressing $60 \mathrm{~V}$ between two TSIA electrodes. Two halves of the specimens were sealed with PVC container of $95 \mathrm{~mm}$ diameter. One side of the container is filled with $3 \% \mathrm{NaCl}$ solution (that side of the cell will be connected to the negative terminal of the power supply); the other side is filled with $0.3 \mathrm{~N} \mathrm{NaOH}$ solution (which will be connected to the positive terminal of the power supply). Current flow is measured at every $30 \mathrm{~min}$ up to $6 \mathrm{~h}$. From the results, using the current and time, chloride permeability is calculated in terms of coulombs at the end of $6 \mathrm{~h}$.

2.2.6. Chloride Diffusion Coefficient. The amount of chloride ion migrating through the concrete specimens after 28 and 90 days of curing was monitored by removing small amount of solution and determining the chloride concentration of these samples after $120 \mathrm{~h}$. Chloride diffusion coefficients were calculated using Nernst-Einstein equation [33].

$$
D=\frac{J R T L}{Z F C_{0} E},
$$

where $D$ is the chloride diffusion coefficient $\left(\mathrm{cm}^{2} / \mathrm{s}\right), J$ is the flux of chloride ions $\left(\mathrm{mol} / \mathrm{cm}^{2} \mathrm{~s}\right), R$ is the gas constant $(8.314 \mathrm{~J} / \mathrm{K} \mathrm{mol}), T$ is the absolute temperature $(300 \mathrm{~K}), L$ is the thickness of the specimen $(\mathrm{cm}), Z$ is the valiancy of chloride ion $(Z=1), F$ is the Faradays constant $\left(9.648 \times 10^{4} \mathrm{~J} / \mathrm{V} \mathrm{mol}\right)$, $C_{0}$ is the initial chloride ion concentration ( $\left.\mathrm{mol} / \mathrm{l}\right)$, and $E$ is the applied potential $(60 \mathrm{~V})$.

2.2.7. Potentiodynamic Polarization Method. Concrete cubes of size $100 \times 100 \times 100 \mathrm{~mm}$ that were cast with TMT rebar of $12 \mathrm{~mm}$ diameter and $75 \mathrm{~mm}$ length (two rebar types) were embedded at a cover depth of $25 \mathrm{~mm}$ as shown in Figure 2. The cubes were cast for OPC, PPC, and PSC with 


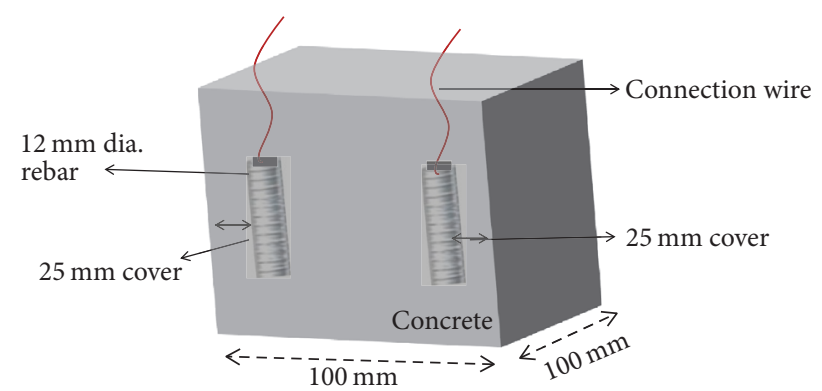

FIGURE 2: Schematic representation of concrete cube specimen used for potentiodynamic polarization and AC-impedance study.

M30 and M40 grade concrete and allowed to cure for 90 days. After 90-day curing the specimens were exposed to the open atmosphere under natural weathering conditions. After two years of exposure, the embedded rebar types in the concrete cube specimens were subjected to potentiodynamic polarization technique using the three-electrode assembly. The rebar embedded in concrete cube acts as a working electrode, stainless steel electrode acts as a counter electrode, and Saturated Calomel Electrode (SCE) acts as a reference electrode. From the polarization technique, the corrosion kinetic parameters such as corrosion current $\left(I_{\text {corr }}\right)$, corrosion potential $\left(E_{\text {corr }}\right)$, cathodic Tafel slope $\left(b_{c}\right)$, and anodic Tafel slope $\left(b_{a}\right)$ were obtained. Both cathodic and anodic polarization curves were recorded potentiodynamically using ACM Instruments, UK. The potentiodynamic conditions correspond to a potential sweep rate of $0.1 \mathrm{mVmin}^{-1}$ and potential ranges of $+0.2 \mathrm{~V}$ to $-0.2 \mathrm{~V}$ versus SCE from the OCP. All the experiments were carried out at the temperature of $32 \pm 1^{\circ} \mathrm{C}$.

2.2.8. AC-Impedance Measurement. The same cube specimens mentioned above were subjected to AC-impedance measurements. The real part $\left(Z^{\prime}\right)$ and the imaginary part $\left(-Z^{\prime \prime}\right)$ of the cell impedance were measured for various frequencies $\left(30 \mathrm{kHz}\right.$ to $0.01 \mathrm{~Hz}$ ). Plots of $Z^{\prime}$ versus $-Z^{\prime \prime}$ were made. The same experimental setup was used here also.

2.2.9. Macrocell Corrosion Studies. A rectangular concrete (M40 grade) specimen of size $279 \mathrm{~mm} \times 152 \mathrm{~mm} \times 114 \mathrm{~mm}$ was designed as per ASTM G 109-07 [34] for macrocell corrosion studies. TMT rebar of $12 \mathrm{~mm}$ diameter and $300 \mathrm{~mm}$ length was used as both anode and cathode in the same concrete. The top mat of rebar acts as the anode and the bottom mat of rebar acts as cathode. The anode to cathode area ratio was maintained as $1: 2$ to induce accelerated corrosion of the embedded anode. The configuration of macrocell specimen is given in Figure 3. In both the anode and cathode $250 \mathrm{~mm}$ length was embedded inside the concrete and the remaining length was used for taking electrical connections with proper insulations.

The specimens were mechanically vibrated. After 24 hours of setting, the specimens were demoulded and cured in distilled water for 90 days. Then the specimens were subjected to alternate wetting and drying cycles. One cycle consists of 15 days of wetting in $3 \% \mathrm{NaCl}$ and 15 days of drying in open atmosphere. Measurements were carried out during the wetting cycle (15th day) as macrocell current showed maximum magnitude due to the low resistivity of the concrete. All the concrete specimens were subjected to 24 complete cycles of exposure period.

\section{Results and Discussion}

3.1. Compressive Strength. The compressive strength of OPC, PPC, and PSC concrete types after 28 and 90 days of curing for M30 and M40 grades of concrete are given in Figures 4 and 5 , respectively.

It was found from Figure 4 that, in M30 grade concrete, the 28-day strength obtained was $37 \mathrm{MPa}, 35.5 \mathrm{MPa}$, and 32.9 MPa for OPC, PPC, and PSC concrete types, respectively. There was a slight increase in the 90-day compressive strength values such as $40 \mathrm{MPa}$ for OPC, $39 \mathrm{MPa}$ for PPC, and 36.9 $\mathrm{MPa}$ for PSC, respectively.

On the other hand, in M40 grade concrete (Figure 5) the 28-day strength obtained was $43.7 \mathrm{MPa}, 41.2 \mathrm{MPa}$, and 43.2 MPa for OPC, PPC, and PSC concrete types, respectively. There was a slight increase in the 90-day compressive strength values such as $47.7 \mathrm{MPa}$ for OPC, $44.3 \mathrm{MPa}$ for PPC, and $46.8 \mathrm{MPa}$ for PSC, respectively.

The magnitude of increase in compressive strength from 28 days to 90 days was found to be similar in M30 grade and M40 grade concrete types. Comparable compressive strength values were obtained for PPC and PSC concrete types when compared with OPC concrete.

3.2. Effective Porosity and Coefficient of Water Absorption. Effective porosity and coefficient of water absorption values calculated for OPC, PPC, and PSC concrete types at 28- and 90-day cured specimens were reported in Table 3. It was observed that both 28- and 90-day cured M30 and M40 grade concrete types showed the effective porosity and coefficient of water absorption in the decreasing order as follows: OPC > PPC > PSC.

Among the three types of concrete used, PSC concrete showed least pores and lower coefficient of water absorption. The same trend is observed in both 28- and 90-day cured M30 and M40 grade concrete types. For example, in the case of PSC, $0.71 \times 10^{-7} \mathrm{~m}^{2} \mathrm{~s}^{-1}$ and $0.62 \times 10^{-7} \mathrm{~m}^{2} \mathrm{~s}^{-1}$ are the coefficient of water absorption values obtained for 28-day cured M30 and M40 grade concrete, respectively. Similarly, for M30 and M40 grade concrete types the coefficient of water absorption values obtained were $0.40 \times 10^{-7} \mathrm{~m}^{2} \mathrm{~s}^{-1}$ and $0.15 \times 10^{-7} \mathrm{~m}^{2} \mathrm{~s}^{-1}$ for 90 -day cured concrete, respectively. The observed values of coefficient of water absorption was attributed to the impermeability nature of the pore structure refinement in PPC and PSC concrete types. The improvement in the permeability characteristics of PPC and PSC is due to the secondary hydration reaction. 


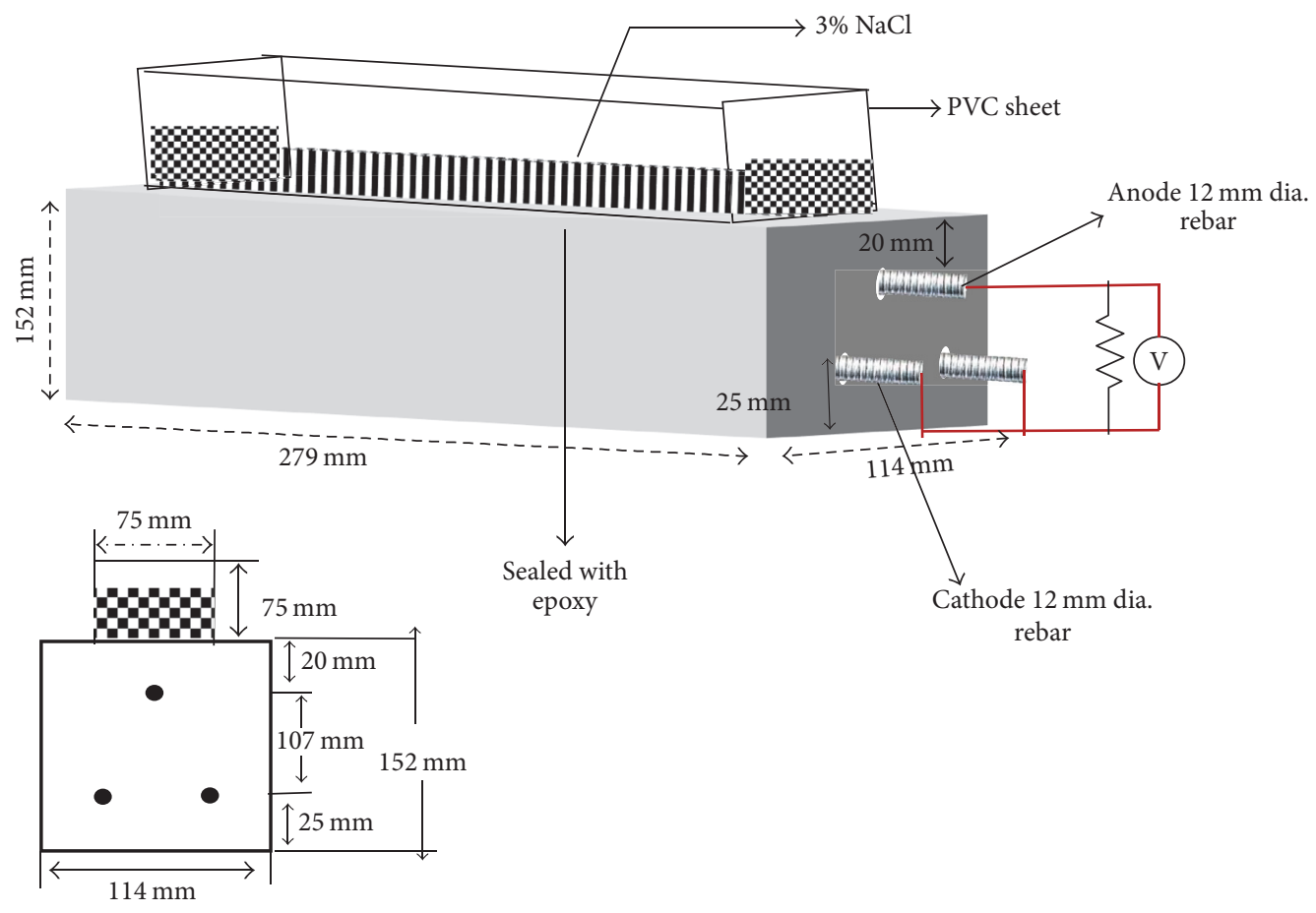

FIgURE 3: Schematic view of macrocell specimen.

TABLE 3: Permeability parameters for OPC, PPC, and PSC M30 and M40 grade concrete types.

\begin{tabular}{|c|c|c|c|c|c|}
\hline \multirow[t]{2}{*}{ Grade } & \multirow[t]{2}{*}{ Type of cement } & \multicolumn{2}{|c|}{ Effective porosity/(\%) } & \multicolumn{2}{|c|}{$\begin{array}{c}\text { Coefficient of water } \\
\text { absorption } /\left(\mathrm{m}^{2} \mathrm{~s}^{-1}\right) \times 10^{-7}\end{array}$} \\
\hline & & 28 days & 90 days & 28 days & 90 days \\
\hline \multirow{3}{*}{ M30 } & OPC & 15.15 & 10.72 & 3.20 & 2.30 \\
\hline & PPC & 14.28 & 9.62 & 2.50 & 2.00 \\
\hline & PSC & 12.61 & 9.57 & 0.71 & 0.40 \\
\hline \multirow{3}{*}{ M40 } & OPC & 13.28 & 9.43 & 3.00 & 1.90 \\
\hline & PPC & 12.42 & 6.79 & 2.90 & 1.10 \\
\hline & PSC & 10.61 & 6.32 & 0.62 & 0.15 \\
\hline
\end{tabular}

In general, the primary hydration reaction in concrete is as follows:

$$
\begin{aligned}
& 2\left(3 \mathrm{CaO} \cdot \mathrm{SiO}_{2}\right)+6 \mathrm{H}_{2} \mathrm{O} \\
& \quad \longrightarrow 3 \mathrm{CaO} \cdot 2 \mathrm{SiO}_{2} \cdot 3 \mathrm{H}_{2} \mathrm{O}+3 \mathrm{Ca}(\mathrm{OH})_{2}
\end{aligned}
$$

But, in PPC and PSC concrete types, the additional secondary hydration reaction is

$$
3 \mathrm{Ca}(\mathrm{OH})_{2}+2 \mathrm{SiO}_{2}+\mathrm{H}_{2} \mathrm{O} \longrightarrow 3 \mathrm{CaO} \cdot 2 \mathrm{SiO}_{2} \cdot 3 \mathrm{H}_{2} \mathrm{O}
$$

In PPC and PSC concrete types, the $\mathrm{Ca}(\mathrm{OH})_{2}$ content reduction is due to the secondary hydration reaction. During the hydration in PPC, lime is consumed but in OPC lime is produced. This is the main advantage of using blended cements to decrease the permeability of the concrete thereby increasing the corrosion resistance properties [35].

3.3. Impressed Voltage Test. The impressed voltage parameters of M30 and M40 grades of OPC, PPC, and PSC concrete types under 28 and 90 days of curing time were given in Table 4. In M30 grade concrete, the maximum anodic current flow measured was found to be 77,65 , and $43 \mathrm{~mA}$ for OPC, PPC, and PSC concrete types, respectively, at 28-day cured specimens. The corresponding reduction in current flow was observed as $15.6 \%$ for PPC and $44.2 \%$ for PSC when compared to OPC. These results clearly indicated that blended cements, namely, PPC and PSC, considerably decreased the anodic current flow. Similar trend was observed in M40 grade concrete. Among the three concrete types, the maximum reduction in current flow was observed for PSC concrete. The reason is that PSC cement consists of higher amount of $\mathrm{Al}_{2} \mathrm{O}_{3}$ (10.5\%) when compared to OPC (5.5\%) and PPC (10\%), which interacted with $\mathrm{Ca}(\mathrm{OH})_{2}$ and favoured more $\mathrm{C}_{3} \mathrm{~A}$ and $\mathrm{C}-\mathrm{S}-\mathrm{H}$ gel. The formation of such compounds reduced the micro- and macropores present in the concrete and this is due to the refinement of the microstructure, considerably reducing the current flow [36]. After 90 days of curing, OPC, PPC, and PSC concrete types showed only a slight decrease 
TABLE 4: Impressed voltage parameters for rebar in OPC, PPC, and PSC M30 and M40 grade concrete types.

\begin{tabular}{|c|c|c|c|c|c|c|}
\hline $\begin{array}{l}\text { Grade and type } \\
\text { of cement }\end{array}$ & $\begin{array}{c}\text { Maximum } \\
\text { anodic current } \\
(\mathrm{mA})\end{array}$ & $\begin{array}{l}(\%) \\
\text { reduction }\end{array}$ & $\begin{array}{l}\text { Time to } \\
\text { cracking } \\
\text { (days) }\end{array}$ & $\begin{array}{c}\text { Free chloride } \\
\text { contents } \\
(\mathrm{ppm})\end{array}$ & $\begin{array}{l}\text { Weight loss } \\
\text { (mg) }\end{array}$ & $\begin{array}{c}\text { Reduction in } \\
\text { corrosion } \\
\text { rate }(\%)\end{array}$ \\
\hline \multicolumn{7}{|c|}{ 28-day cured concrete specimens } \\
\hline OPC M30 & 77 & - & 07 & 4680 & 44.3210 & - \\
\hline PPC M30 & 65 & 15.6 & 08 & 3560 & 25.3120 & 42.9 \\
\hline PSC M30 & 43 & 44.2 & 10 & 3253 & 7.9140 & 82.1 \\
\hline OPC M40 & 72 & - & 10 & 3789 & 35.3020 & - \\
\hline PPC M40 & 56 & 22.2 & 12 & 3420 & 14.1410 & 59.7 \\
\hline PSC M40 & 39 & 45.8 & 14 & 3200 & 2.4650 & 93.0 \\
\hline \multicolumn{7}{|c|}{ 90-day cured concrete specimens } \\
\hline OPC M30 & 74 & - & 08 & 4200 & 33.5780 & - \\
\hline PPC M30 & 58 & 21.62 & 09 & 3165 & 12.2290 & 63.6 \\
\hline PSC M30 & 43 & 41.89 & 11 & 2880 & 1.7030 & 94.9 \\
\hline OPC M40 & 60 & - & 14 & 3040 & 23.4530 & - \\
\hline PPC M40 & 43 & 28.30 & 18 & 2840 & 11.9420 & 49.0 \\
\hline PSC M40 & 26 & 56.66 & 20 & 2640 & 1.1470 & 95.1 \\
\hline
\end{tabular}

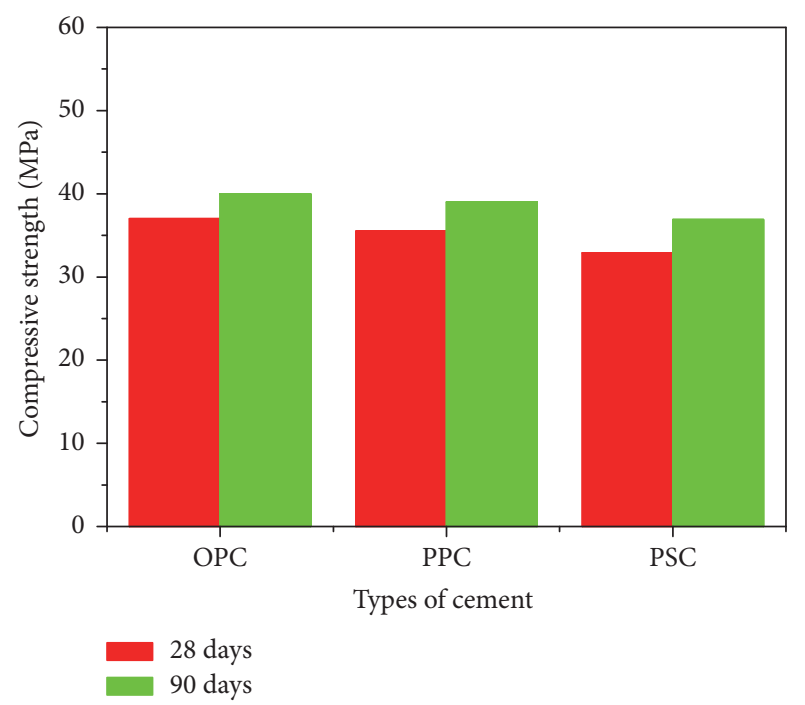

FIGURE 4: Comparison of compressive strength of M30 grade OPC, PPC, and PSC concrete types.

in the magnitude of current flow in both M30 and M40 grade concrete types. The percentage reduction in the current flow was $41.89 \%$ and $56.66 \%$ for PSC system at 28 and 90 days of curing period. These data confirmed the impermeability nature of blended cement concrete types.

3.3.1. Time Taken for Initial Crack. The time taken for initial crack measured for 28- and 90-day cured OPC, PPC, and PSC concrete types was given in Table 4 . The results indicated that both 28- and 90-day cured M30 and M40 grade concrete types showed the following order with respect to time taken for initial crack.

$$
\mathrm{OPC}<\mathrm{PPC}<\text { PSC }
$$

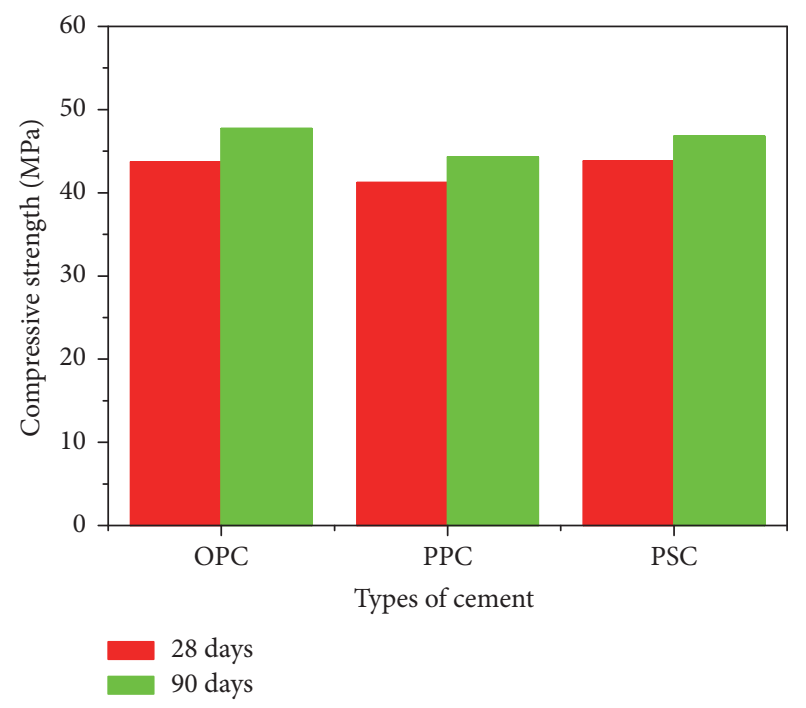

Figure 5: Comparison of compressive strength of M40 grade OPC, PPC, and PSC concrete types.

Among the three concrete types, PSC concrete in M30 and M40 grades, 28- as well as 90-day cured specimens showed the longest time taken for initial crack. For example, for 28-day cured M30 and M40 concrete, time taken for initial crack observed was at 10 and 14 days, respectively. Similar trend was observed for 90-day cured concrete.

The better performance of PSC is due to the following reason. Aluminate phase is the most responsible one for binding the chlorides into complex forms. Fixing of chloride in concrete by the formation of complex aluminate phases has been reported by Karthick et al. [37]. About $50 \%$ to $80 \%$ of chloride ions are bound by aluminate phases by the action of calcium 


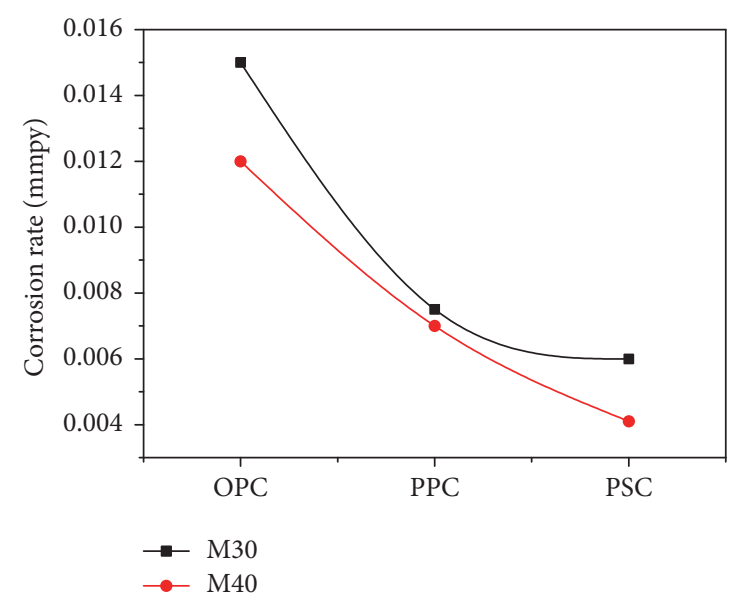

FIGURE 6: Comparison of corrosion rate of rebar in OPC, PPC, and PSC concrete types obtained by impressed voltage test (28-day cured specimens).

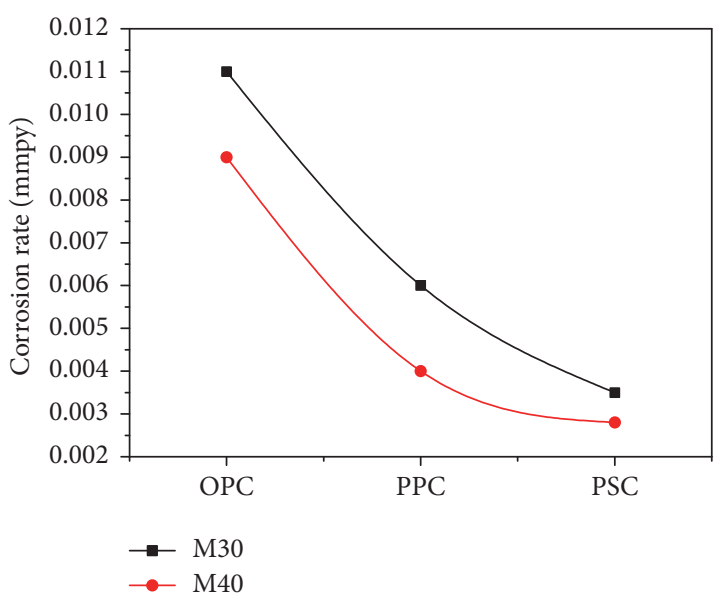

FIGURE 7: Comparison of corrosion rate of rebar in OPC, PPC, and PSC concrete types obtained by impressed voltage test (90-day cured specimens).

oxide and aluminate with chloride, forming calcium chloroaluminate complexes $\left(\mathrm{CaO} \cdot \mathrm{Al}_{2} \mathrm{O}_{3} \cdot \mathrm{NaCl}_{2} \cdot 10 \mathrm{H}_{2} \mathrm{O}\right)$. With the result, the time taken for initial crack was increased.

The free chloride contents showed the lower values for PSC concrete. This can be attributed to the formation of free chlorides into complex form. The mechanism of the formation of complex, namely, Friedel salt, is by the precipitation method.

3.3.2. Corrosion Rate of Embedded Steel. The corrosion rates of embedded steel in OPC, PPC, and PSC were given in Figures 6 and 7, respectively.

The corrosion rates of steel calculated for 28 days cured M30 OPC, PPC, and PSC concrete types were found to be $0.0150,0.0075$, and $0.0060 \mathrm{mmpy}$, respectively. These results showed that blended cements, namely, PPC and PSC, considerably decreased the corrosion rate of embedded steel by 2 times and 2.5 times. Similar trend was also observed in
M40 grade concrete. PPC and PSC concrete types showed 1.7 times and 3 times reduction in corrosion rate when compared to OPC concrete.

The corrosion rate values calculated for 90 days cured M30 OPC, PPC, and PSC concrete types were found to be $0.0110,0.0060$, and $0.0035 \mathrm{mmpy}$, respectively. These results showed that blended cements, namely, PPC and PSC, considerably decreased the corrosion rate of embedded steel by 2 and 3 times, respectively. A similar trend was also observed in M40 grade concrete. PPC and PSC concrete types showed 2.2 and 3.3 times reduction in corrosion rate when compared to OPC concrete.

For reinforcement corrosion to occur, a critical quantity of chloride is required at the steel/concrete interface. In OPC, the critical chloride is reached in a very short time, whereas it took more time for PPC and PSC concrete types as evidenced by the time taken for initial crack. The considerable reduction in corrosion rate of the blended cements was attributed to the secondary pozzolanic reaction in blended cements which favoured more C-S-H gel formation and interconnected the micropores present in the blended cements. Moreover, the PSC showed the least corrosion rate values because, in addition to the secondary pozzolanic reaction, the higher $\mathrm{Al}_{2} \mathrm{O}_{3}$ content adsorbed more free chloride and formed chloroaluminate complex [37]. Thus, the free chlorides mainly responsible for inducing the reinforcement corrosion were considerably reduced and hence a marked reduction in corrosion rate values was observed.

Better corrosion resistant properties were observed for PSC concrete that exhibited the minimum current flow, lowest free chloride contents, and lower corrosion rate.

3.4. Rapid Chloride Permeability Test. The amount of charge that passed (coulombs) through OPC, PPC, and PSC concrete types cured after 28 and 90 days was reported in Table 5. In M30 grade 28-day cured concrete showed 669, 281, and 226 coulombs for OPC, PPC, and PSC concrete types, respectively. The results obtained for M40 grade concrete showed 626, 261, and 204 coulombs for OPC, PPC, and PSC concrete types, respectively. This showed that, in M40 grade concrete, due to the higher cement content, the higher reactivity of $\mathrm{Ca}(\mathrm{OH})_{2}$ with $\mathrm{SiO}_{2}$ leads to the formation of C$\mathrm{S}-\mathrm{H}$ gel which reduced the micro- and macropores present in the concrete. Besides, PSC and PPC cement consists of higher amount of $\mathrm{Al}_{2} \mathrm{O}_{3}$ (10.0 to 10.5\%) when compared to OPC (5.5\%), which interacted with $\mathrm{Ca}(\mathrm{OH})_{2}$ and favoured formation of calcium chloroaluminate complexes (chloride binding effect) which made the concrete more impermeable [38]. For this reason, the amount of charge that passed reduced considerably in M40 grade concrete when compared to M30 grade concrete. The results indicated that the amount of charge that passed considerably reduced in the case of both M30 and M40 grade PPC (2.38 and 2.39 times) and PSC (2.96 and 3.06 times) concrete types when compared to OPC concrete. The refinement of the pore structure occurring in blended cements considerably reduced the permeation of aggressive chloride ions. The same trend was observed by Saraswathy and Song, by replacing 15 with 30\% RHA [30]. 
TABLE 5: Rapid chloride permeability test (RCPT) parameters for OPC, PPC, and PSC M30 and M40 grade concrete types.

\begin{tabular}{|c|c|c|c|c|c|c|}
\hline & & 28 days & & & 90 days & \\
\hline Grade & Charge passed (coulomb) & $\begin{array}{c}\text { Free chloride } \\
\text { contents } \\
\text { (ppm) }\end{array}$ & $\begin{array}{c}\text { Chloride } \\
\text { diffusion } \\
\text { coefficient } \\
\left(\mathrm{cm}^{2} \mathrm{~s}^{-1}\right) \times 10^{-10}\end{array}$ & $\begin{array}{c}\text { Charge } \\
\text { passed } \\
\text { (coulombs) }\end{array}$ & $\begin{array}{l}\text { Free chloride } \\
\text { contents } \\
(\mathrm{ppm})\end{array}$ & $\begin{array}{c}\text { Chloride } \\
\text { diffusion } \\
\text { coefficient } \\
\left(\mathrm{cm}^{2} \mathrm{~s}^{-1}\right) \times 10^{-10}\end{array}$ \\
\hline OPC M30 & 669 & 749 & 2.4 & 630 & 579 & 1.9 \\
\hline PPC M30 & 281 & 681 & 1.8 & 220 & 528 & 1.5 \\
\hline PSC M30 & 226 & 481 & 1.0 & 200 & 380 & 1.4 \\
\hline OPC M40 & 626 & 540 & 1.8 & 600 & 520 & 1.4 \\
\hline PPC M40 & 261 & 532 & 1.5 & 180 & 483 & 0.8 \\
\hline PSC M40 & 204 & 596 & 0.5 & 200 & 393 & 0.6 \\
\hline
\end{tabular}

3.4.1. Chloride Diffusion Coefficient. The chloride diffusion coefficient (CDC) calculated for 28- and 90-day cured OPC, PPC, and PSC concrete types was reported in Table 5. The results indicated that both 28 - and 90-day cured M30 and M40 grade concrete types showed the decreasing trend as follows:

$$
\mathrm{OPC}>\mathrm{PPC}>\text { PSC }
$$

In PSC M30 and M40 grade 28- as well as 90-day cured concrete showed the least chloride diffusion coefficient (CDC) values. For example, in M30 grade 28-day cured concrete the CDC values are found to be $1.8 \times 10^{-10} \mathrm{~cm}^{2} \mathrm{~s}^{-1}$ and $1.0 \times 10^{-10} \mathrm{~cm}^{2} \mathrm{~s}^{-1}$ for PPC and PSC concrete types, respectively. In M40 grade, 90-day cured concrete CDC values are $0.8 \times 10^{-10} \mathrm{~cm}^{2} \mathrm{~s}^{-1}$ and $0.6 \times 10^{-10} \mathrm{~cm}^{2} \mathrm{~s}^{-1}$ for PPC and PSC concrete types, respectively. For high performance concrete, the CDC values were found to be of the order of $10^{-12} \mathrm{~cm}^{2} \mathrm{~s}^{-1}$. The considerable lower CDC values for blended cements were attributed to their impermeability nature that is due to the refinement of their pore structure [39].

3.5. Potentiodynamic Polarization Technique. Potentiodynamic polarization curves obtained for the corrosion of rebar in various types of cement concrete were shown in Figure 8. The corrosion kinetic parameters for rebar embedded in OPC, PPC, and PSC for M30 and M40 grade and 90-day cured concrete specimens were given in Table 6.

The corrosion potential of rebar in M30 concrete types from OPC, PPC, and PSC are $-397,-303$, and $-299 \mathrm{mV}$, respectively. PSC concrete improves the corrosion resistance of rebar when compared to OPC concrete. There is a difference of $-97 \mathrm{mV}$ which moves in the positive direction for PSC cement concrete. The corrosion rates of rebar types in OPC, PPC, and PSC are $6.9922 \times 10^{-3}, 1.6902 \times 10^{-3}$, and $1.4448 \times 10^{-3}$ mmpy, respectively. The corrosion rate of PPC and PSC was reduced 4.088 and 4.78 times when compared to OPC. The corrosion current density for rebar in three types of cement concrete at the end of exposure is as follows:

$$
\begin{array}{ccc}
1.4449 \times 10^{-4} \mathrm{~mA} \cdot \mathrm{cm}^{-2} & <1.6902 \times 10^{-4} \mathrm{~mA} \cdot \mathrm{cm}^{-2}<6.9922 \times 10^{-4} \mathrm{~mA} \cdot \mathrm{cm}^{-2} \\
\text { PSC } & \text { PPC } & \text { OPC. }
\end{array}
$$

In M40 grade concrete, the measured corrosion potential was $-301,-263$, and $-258 \mathrm{mV}$ versus SCE for OPC, PPC, and PSC, respectively. The variation in potential for M40 PPC and
PSC concrete types when compared to OPC was found to be less than M30 grade concrete. The corrosion current density for M40 concrete follows the same order as M30 concrete:

$$
\begin{array}{ccc}
2.491 \times 10^{-4} \mathrm{~mA} \cdot \mathrm{cm}^{-2} & <1.9589 \times 10^{-4} \mathrm{~mA} \cdot \mathrm{cm}^{-2} & <1.674 \times 10^{-4} \mathrm{~mA} \cdot \mathrm{cm}^{-2} \\
\text { PSC } & \text { PPC } & \text { OPC. }
\end{array}
$$

The PSC and PPC concrete types exhibit lower corrosion current density and lowest corrosion rate when compared to their OPC concrete counterpart.
3.6. AC-Impedance Measurements. Impedance diagrams obtained for the frequency range $0.01 \mathrm{~Hz}$ to $30 \mathrm{kHz}$ at the OCP for the corrosion of rebar in different concrete types 


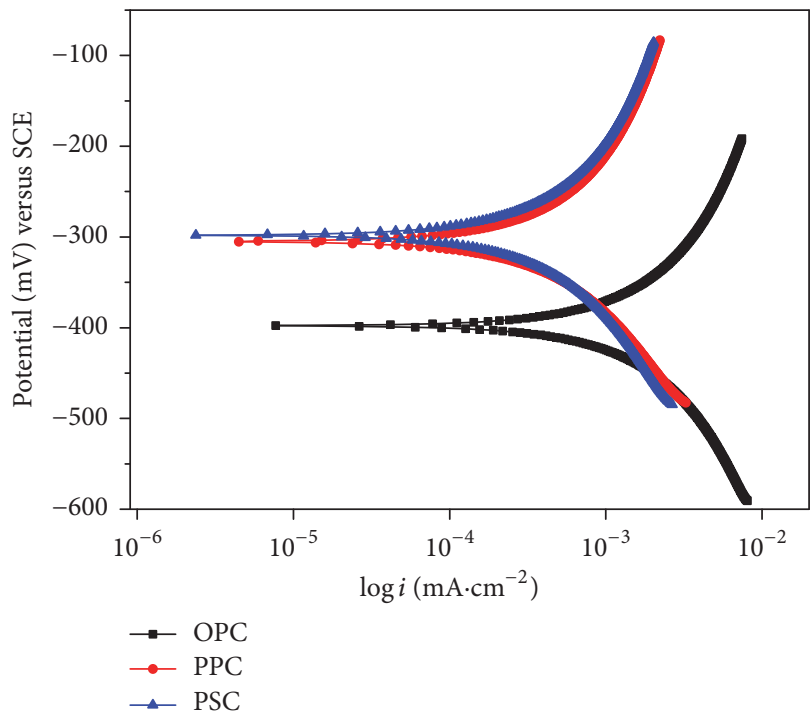

(a)

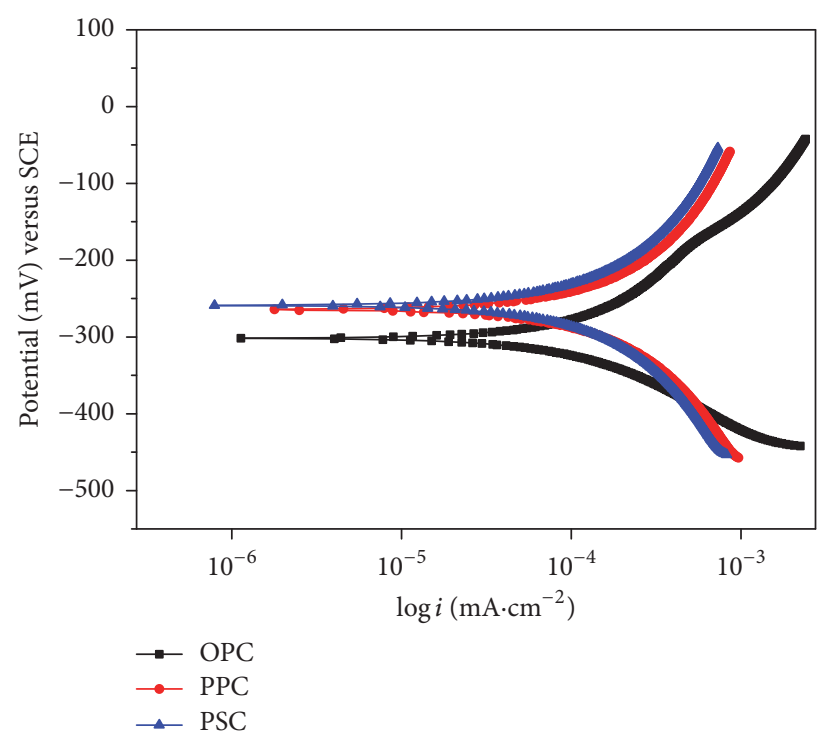

(b)

FIGURE 8: Potentiodynamic polarization curves for TMT rebar embedded in OPC, PPC, and PSC M30 (a) and M40 (b) grade concrete types (90-day cured specimens).

TABLE 6: Potentiodynamic polarization parameters for the corrosion of rebar embedded in OPC, PPC, and PSC M40 grade concrete (90-day cured specimens).

\begin{tabular}{|c|c|c|c|c|c|c|}
\hline \multirow{3}{*}{ System } & \multicolumn{6}{|c|}{ Various grades of concrete } \\
\hline & \multicolumn{3}{|c|}{ M30 } & \multicolumn{3}{|c|}{ M40 } \\
\hline & $\begin{array}{c}E_{\text {corr }} \\
\text { (mV versus } \\
\text { SCE) }\end{array}$ & $\frac{I_{\text {corr }}}{\left(\mathrm{mA} \cdot \mathrm{cm}^{-2}\right) \times 10^{-4}}$ & $\begin{array}{l}\text { Corrosion rate } \\
(\mathrm{mmpy}) \times 10^{-3}\end{array}$ & $\begin{array}{c}E_{\text {corr }} \\
(\mathrm{mV} \text { versus } \\
\text { SCE })\end{array}$ & $\begin{array}{c}I_{\text {corr }} \\
\left(\mathrm{mA} \cdot \mathrm{cm}^{-2}\right) \times 10^{-5}\end{array}$ & $\begin{array}{l}\text { Corrosion rate } \\
(\mathrm{mmpy}) \times 10^{-4}\end{array}$ \\
\hline OPC & -397 & 6.9922 & 8.0082 & -301 & 2.1496 & 2.491 \\
\hline PPC & -303 & 1.6902 & 1.9589 & -263 & 1.6902 & 1.9589 \\
\hline PSC & -299 & 1.4448 & 1.674 & -258 & 1.4448 & 1.674 \\
\hline
\end{tabular}

were shown in Figure 9. The corrosion parameters for rebar types in OPC, PPC, and PSC of M30 and M40 grade 90-day cured concrete types are given in Table 7 . It is seen from the figure that the impedance diagram is not a perfect semicircle. This difference has been attributed to frequency dispersion.

From the table, it is found that $R_{\mathrm{ct}}$ (charge transfer resistance) values were found to be higher for both PPC and PSC when compared to OPC in both M30 and M40 grade concrete types, which indicates that PPC and PSC have better corrosion resistance than OPC. The corrosion rate values in M30 grade PPC and PSC concrete types were observed to be 1.12 and 1.27 times less when compared with OPC. In M40 grade concrete $R_{\mathrm{ct}}$ values observed for OPC, PPC, and PSC were $1.399 \times 10^{6}, 1.594 \times 10^{6}$, and $1.714 \times 10^{6} \mathrm{ohm} \cdot \mathrm{cm}^{2}$, respectively. This indicated that M40 grade concrete has two orders of magnitude higher corrosion resistance than M30 grade concrete.

Nyquist plots clearly indicated that rebar types embedded in PSC and PPC concrete performed better than OPC. The corrosion rates of rebar in various concrete types at the end of 24 months' exposure in M30 and M40 grade concrete types are as follows:

$$
\begin{array}{ccc}
8.728 \times 10^{-3} \mathrm{mmpy} & <7.782 \times 10^{-3} \mathrm{mmpy} & <6.873 \times 10^{-3} \mathrm{mmpy} \\
\text { M30 PSC } & \text { PPC } & \text { OPC } \\
2.161 \times 10^{-4} \mathrm{mmpy} & <1.897 \times 10^{-4} \mathrm{mmpy} & <1.764 \times 10^{-4} \mathrm{mmpy} \\
\text { M40 PSC } & \text { PPC } & \text { OPC. }
\end{array}
$$


TABLE 7: AC-impedance parameters for the corrosion of rebar embedded in OPC, PPC, and PSC M40 grade concrete (90-day cured specimens).

\begin{tabular}{lcccccc}
\hline & \multicolumn{4}{c}{ Various grades of concrete } & \multicolumn{2}{c}{ M40 } \\
System & $\begin{array}{c}\text { M30 } \\
R_{\mathrm{ct}}\end{array}$ & $\begin{array}{c}I_{\text {corr }} \\
\left(\mathrm{ohms} \cdot \mathrm{cm}^{2}\right) \times 10^{4}\end{array}$ & $\begin{array}{c}\text { Corrosion rate } \\
(\mathrm{mmpy}) \times 10^{-3}\end{array}$ & $\begin{array}{c}R_{\mathrm{ct}} \\
\left(\mathrm{ohms} \cdot \mathrm{cm}^{2}\right) \times 10^{6}\end{array}$ & $\begin{array}{c}I_{\text {corr }} \\
\left(\mathrm{mA} / \mathrm{cm}^{2}\right) \times 10^{-5}\end{array}$ & $\begin{array}{c}\text { Corrosion rate } \\
\left(\mathrm{mmpy}^{2} \times 10^{-4}\right.\end{array}$ \\
\hline OPC & 3.464 & 7.531 & 8.728 & 1.399 & 1.865 & 2.161 \\
PPC & 3.885 & 6.715 & 7.782 & 1.594 & 1.637 & 1.897 \\
PSC & 4.399 & 5.930 & 6.873 & 1.714 & 1.522 & 1.764 \\
\hline
\end{tabular}

From the results it is observed that PSC concrete showed the higher charge transfer resistance and lowest corrosion rate when compared to PPC and OPC concrete types.

3.7. Macrocell Corrosion Studies. The half-cell potential of steel measured periodically against SCE with time for OPC, PPC, and PSC for M30 and M40 grade 90-day cured concrete types was shown in Figures 10 and 11. It was observed from Figure 10 that steel embedded in M30 grade OPC, PPC, and PSC concrete types is showing active condition within 3, 4, and 5 cycles of exposure, respectively. After 5 cycles, all the three types of concrete types were showing the potential more negative than $-275 \mathrm{mV}$ versus SCE indicating the active condition of the rebar due to the ingress of chloride ions, whereas in M40 grade concrete the OPC, PPC, and PSC reached the active condition at 7, 9, and 11 cycles of exposure, respectively. In M30 grade concrete, the potential gets stabilized after 12 cycles of exposure for all the types of concrete types and it reached a maximum active potential of $-610 \mathrm{mV},-530 \mathrm{mV}$, and $-501 \mathrm{mV}$ for OPC, PPC, and PSC, respectively, at the end of 24 cycles. In M40 grade concrete, after 11 cycles of exposure, both PPC and PSC have shown gradual increase in potential to the active state, reaching a potential of $-420 \mathrm{mV}$ and $-400 \mathrm{mV}$ at the end of 24 th cycle. But OPC has shown a more negative potential of $-520 \mathrm{mV}$ at the end of 24th cycle. These results indicated that the PSC concrete performed better than PPC and OPC concrete types.

The macrocell current measured periodically with time for M30 and M40 grade OPC, PPC, and PSC concrete types is shown in Figures 12 and 13. From Figure 12, it is observed that M30 OPC concrete that crossed the critical current of $10 \mu \mathrm{A}$ showed the higher magnitude of macrocell current flow at the end of 24 cycles of exposure indicating the severe corrosion of the embedded steel. The macrocell current measured at the end of the 24 th cycle was $72 \mu \mathrm{A}, 60 \mu \mathrm{A}$, and $54 \mu \mathrm{A}$ for OPC, PPC, and PSC concrete types, respectively.

From Figure 13 it is observed that in M40 grade concrete OPC reached the threshold macrocell current of $10 \mu \mathrm{A}$ within 2 cycles of exposure and PPC and PSC reached the microcell current at 4 th and 6 th cycles of exposure. The macrocell current measured at the end of 24th cycle was $60 \mu \mathrm{A}, 45 \mu \mathrm{A}$, and $34 \mu \mathrm{A}$ for OPC, PPC, and PSC, respectively.

The total integrated current calculated (ASTM G109) with time for M30 grade OPC, PPC, and PSC concrete types is illustrated in Figure 14. From the figure, it was observed that at the end of the exposure (24th cycle) OPC concrete showed the higher value of 1200 coulombs, whereas PPC and PSC exhibited 800 and 500 coulombs, respectively. Figure 15 shows the total integrated current versus number of cycles for M40 grade OPC, PPC, and PSC concrete types. From the figure, it is observed that the coulomb values observed for OPC, PPC, and PSC were 900, 700, and 600, respectively. In both M30 and M40 grades of concrete PPC and PSC showed a coulomb value of less than 1000 indicating the blended cements have very low chloride penetration. But OPC showed 1200 coulombs in M30 grade and 900 coulombs in M40 grade concrete types. In M30 grade concrete OPC is graded as a low permeable concrete. But in both the grades of concrete PPC and PSC were graded as a very low permeable concrete as per ASTM C1202-12 [32].

In the case of OPC system, the availability of chloride ions that occupied the defect position and reacted with ferrous ions initiated the corrosion process. But in the case of PPC and PSC concrete types, the availability of free chloride is significantly reduced due to the formation of chloroaluminate complexes [37]. As a result, there is a considerable reduction in the magnitude of current flow which was observed in PPC and PSC concrete types.

\section{Conclusions}

The following conclusions were drawn from the above investigation:

(i) Mechanical properties are not altered by using blended cements, but corrosion resistant properties are greatly improved.

(ii) The effective porosity and coefficient of water absorption values showed the decreasing order as follows: $\mathrm{OPC}>\mathrm{PPC}>\mathrm{PSC}$. Among the three types of concrete used, PSC concrete showed the least pores and lower coefficient of water absorption.

(iii) Better corrosion resistant properties were observed for PSC concrete types by showing a minimum current flow, lowest free chloride contents, and lesser corrosion rate, and thereby the time taken for initiation of crack period was extended in accelerated impressed voltage technique. 

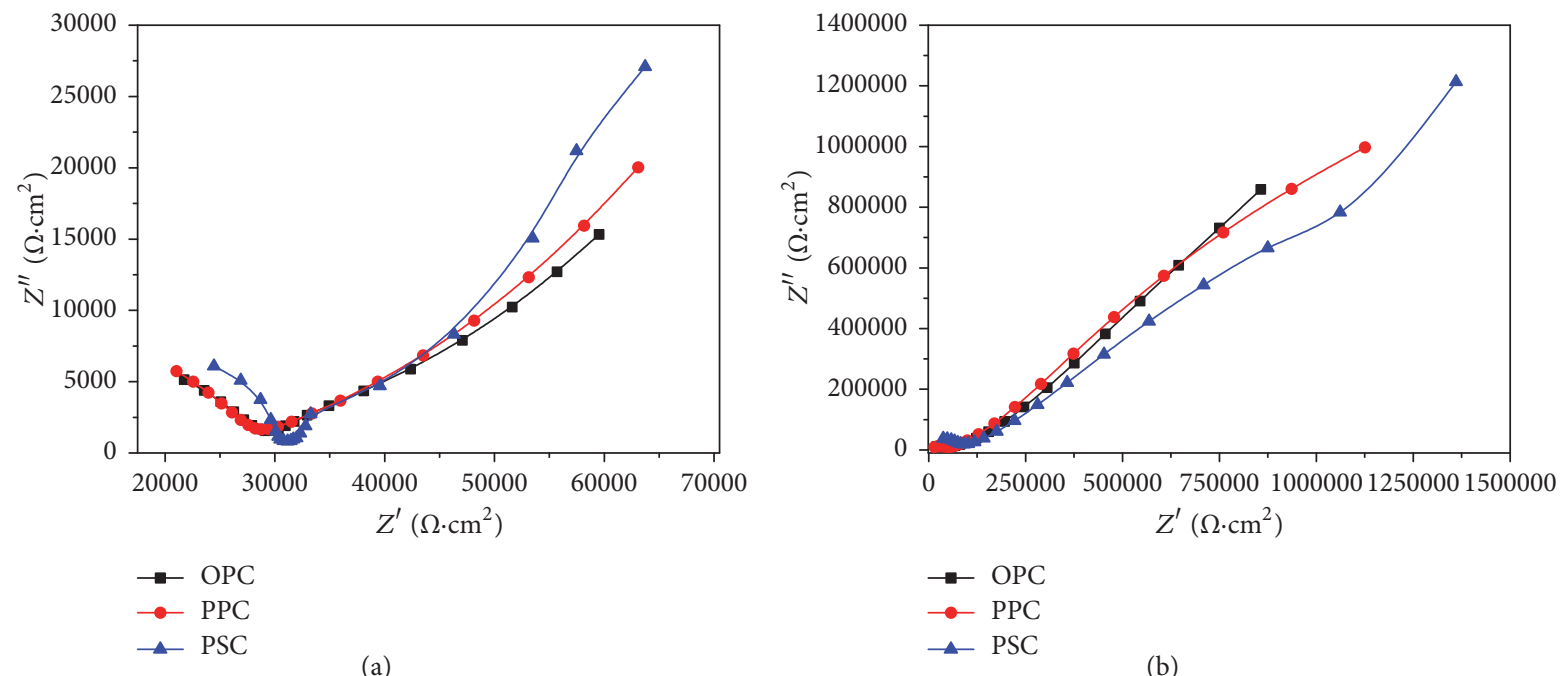

FIGURE 9: Nyquist plots for TMT rebar embedded in OPC, PPC, and PSC M30 (a) and M40 (b) grade concrete types (90-day cured specimens).

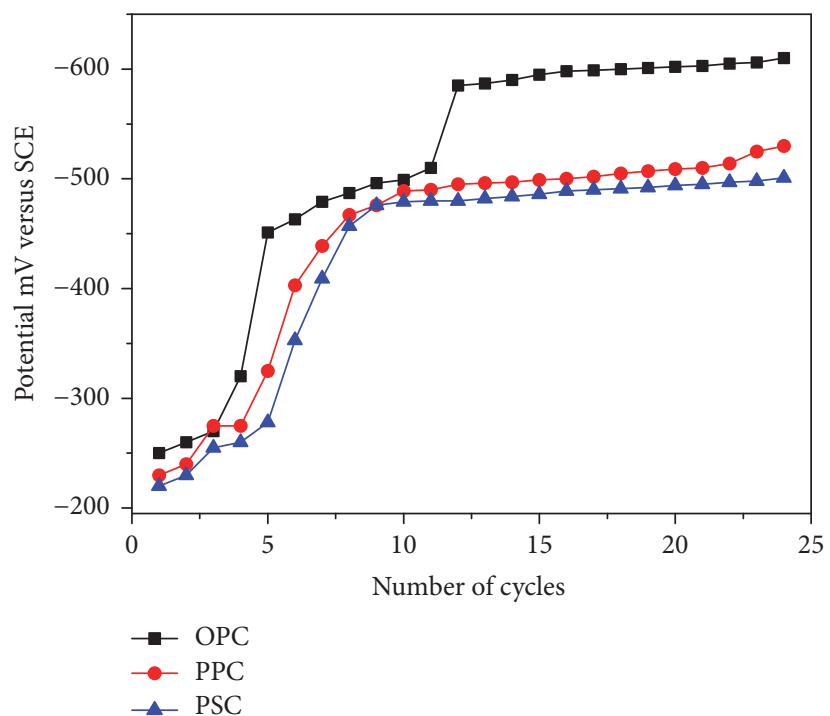

FIGURE 10: Potential versus number of cycles of exposure for rebar in OPC, PPC, and PSC M30 grade concrete types (90-day cured specimens) under macrocell condition.

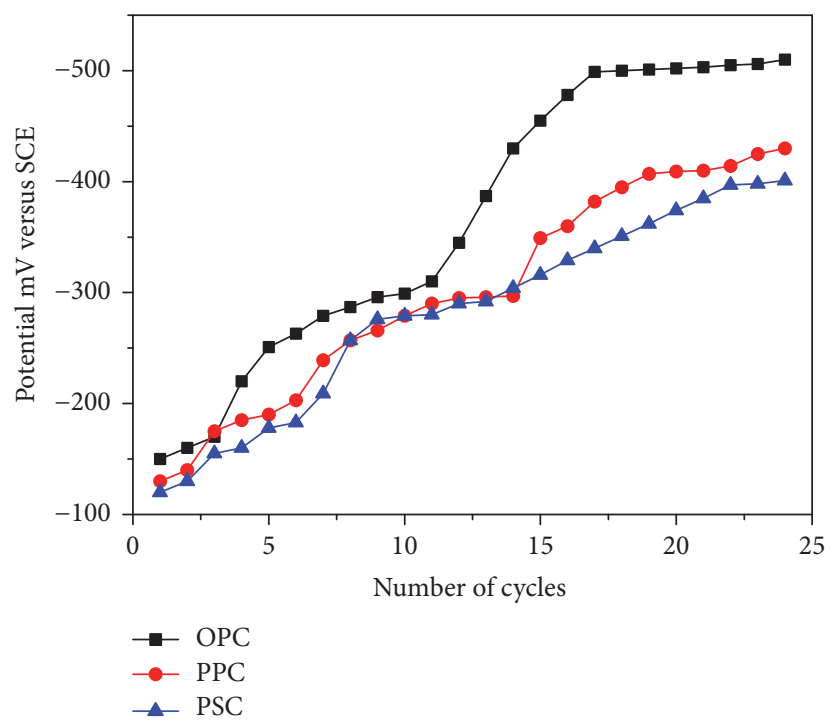

FIGURE 11: Potential versus number of cycles of exposure for rebar in OPC, PPC, and PSC M40 grade concrete types (90-day cured specimens) under macrocell condition. 


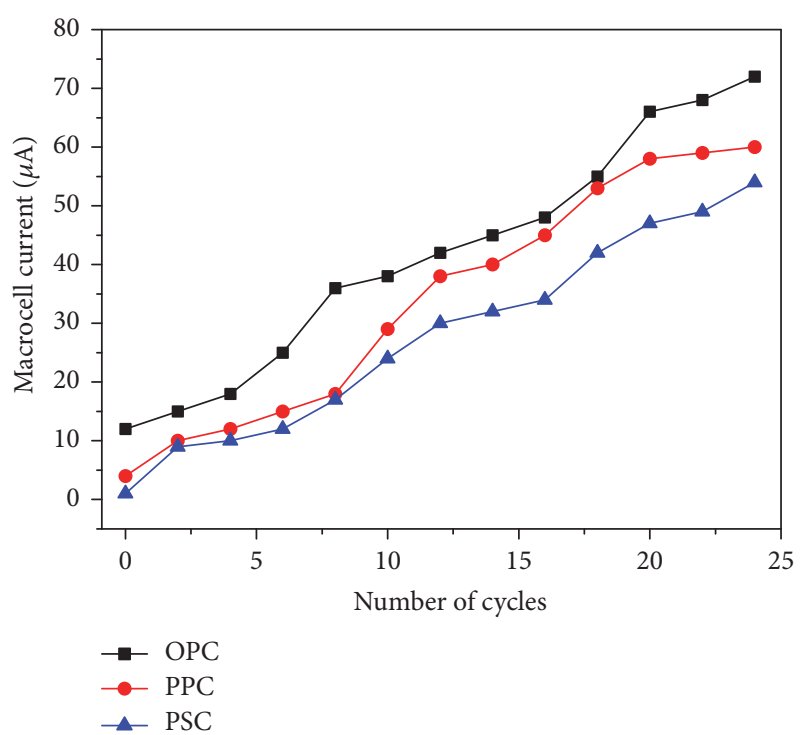

Figure 12: Macrocell current versus number of cycles of exposure for rebar in OPC, PPC, and PSC M30 grade concrete types (90-day cured specimens) under macrocell condition.

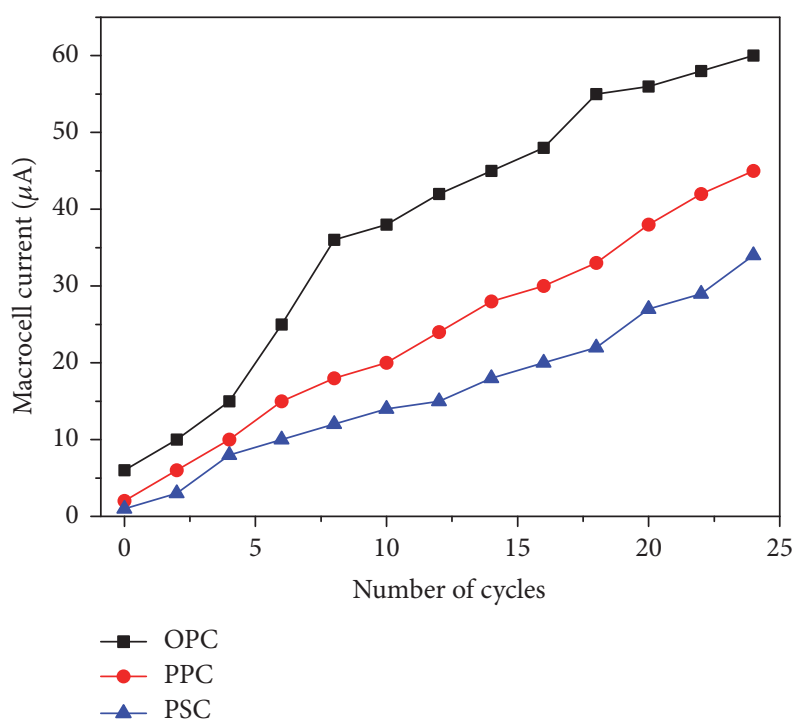

FIGURE 13: Macrocell current versus number of cycles of exposure for rebar in OPC, PPC and PSC M40 grade concrete types (90 days cured specimens) under macrocell condition.

(iv) In the case of M30 grade concrete cured for 28 days, the corrosion rate was considerably decreased by 2 and 2.5 times for PPC and PSC, respectively.

(v) In the case of M40 grade concrete cured for 28 days, PPC and PSC concrete types showed 1.7 and 3 times reduction in corrosion rate when compared to the OPC concrete.

(vi) RCPT indicated that both 28- and 90-day cured M30 and $\mathrm{M} 40$ grade concrete types showed the decrease in $\mathrm{CDC}$ values as follows: $\mathrm{OPC}>\mathrm{PPC}>\mathrm{PSC}$.

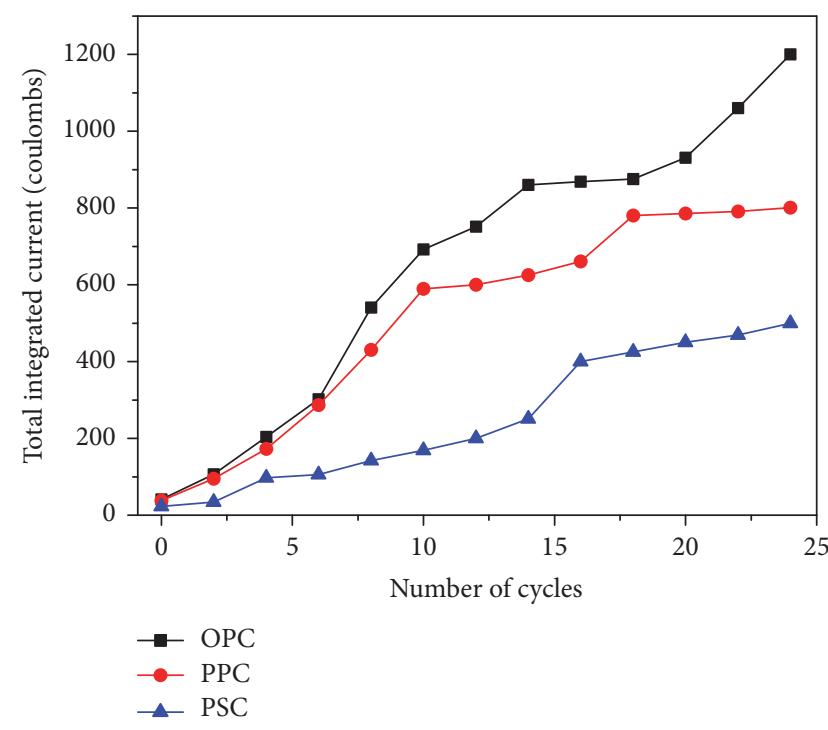

FIgURE 14: Total integrated current versus number of cycles of exposure for rebar in OPC, PPC, and PSC M30 grade concrete types (90-day cured specimens) under macrocell condition.

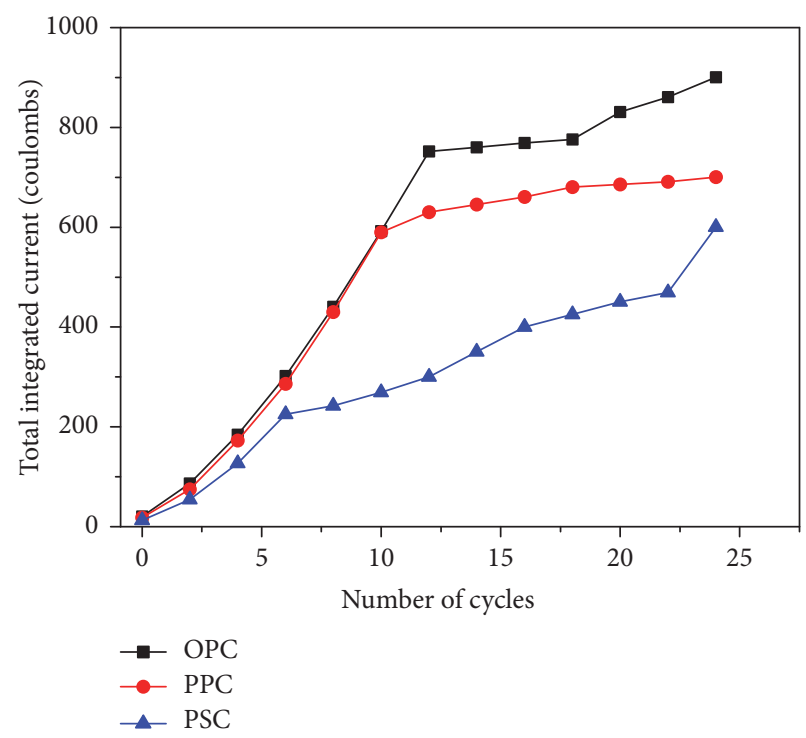

FIgURE 15: Total integrated current versus number of cycles of exposure for rebar in OPC, PPC, and PSC M40 grade concrete types (90-day cured specimens) under macrocell condition.

(vii) Macrocell corrosion studies revealed that PPC and PSC concrete types are graded as very low chloride permeability concrete in both M30 and M40 grade concrete types.

(viii) Electrochemical studies also proved beyond doubt that PSC concrete performed better than PPC and OPC concrete types.

\section{Conflicts of Interest}

The authors declare that there are no conflicts of interest regarding the publication of this paper. 


\section{Acknowledgments}

This research was supported by the Basic Science Research Program through the National Research Foundation of Korea (NRF) funded by the Ministry of Science, ICT \& Future Planning (no. 2015R1A5A1037548).

\section{References}

[1] E. Güneyisi, T. Özturan, and M. Gesoǧlu, "Effect of initial curing on chloride ingress and corrosion resistance characteristics of concretes made with plain and blended cements," Building and Environment, vol. 42, no. 7, pp. 2676-2685, 2007.

[2] V. Saraswathy and H.-W. Song, "Improving the durability of concrete by using inhibitors," Building and Environment, vol. 42, no. 1, pp. 464-472, 2007.

[3] H.-W. Song and V. Saraswathy, "Corrosion monitoring of reinforced concrete structures: a review," International Journal of Electrochemical Science, vol. 2, no. 1, pp. 1-28, 2007.

[4] T. H. Wee, A. K. Suryavanshi, and S. S. Tin, "Evaluation of rapid chloride permeability test (RCPT) results for concrete containing mineral admixtures," ACI Structural Journal, vol. 97, no. 2, pp. 221-232, 2000.

[5] G. Chirag and J. Aakash, "Green concrete: efficient and ecofriendly construction materials," in Proceedings of the nternational Journal of Research in Engineering and Technology, vol. 2, pp. 259-264, 2014.

[6] V. M. Malhotra, Role of supplementary cementing materials in reducing greenhouse gas emissions, Report MTL 98-03 (OP\&) Natural resource Ottawa, Ottawa, Canada, 1998.

[7] E. Guneyisi, T. Ozturan, and M. Gesoglu, "Laboratory investigation of chloride permeability for high performance concrete containing fly ash and silica fume," R. K. Dhir, Ed., pp. 295-305, Dundee, Scotland, 2002.

[8] V. Saraswathy, S. Muralidharan, R. M. Kalyanasundaram, K. Thangavel, and S. Srinivasan, "Evaluation of a composite corrosion-inhibiting admixture and its performance in concrete under macrocell corrosion conditions," Cement and Concrete Research, vol. 31, no. 5, pp. 789-794, 2001.

[9] V. Saraswathy, S. Muralidharan, K. Thangavel, and S. Srinivasan, "Activated fly ash cements: Tolerable limit of replacement for durable steel reinforced concrete," Advances in Cement Research, vol. 14, no. 1, pp. 9-16, 2002.

[10] V. Saraswathy, S. Muralidharan, K. Thangavel, and S. Srinivasan, "Influence of activated fly ash on corrosion-resistance and strength of concrete," Cement and Concrete Composites, vol. 25, no. 7, pp. 673-680, 2003.

[11] V. Saraswathy, S. Muralidharan, K. Thangavel, and S. Srinivasan, "Electrochemical studies on the corrosion performance of activated fly ash blended cements," Materials Engineering, vol. 14, pp. 261-283, 2003.

[12] S. Muralidharan, V. Saraswathy, S. P. M. Nima, and N. Palaniswamy, "Evaluation of a composite corrosion inhibiting admixtures and its performance in Portland pozzolana cement," Materials Chemistry and Physics, vol. 86, no. 2-3, pp. 298-306, 2004.

[13] G. A. Habeeb and H. B. Mahmud, "Study on properties of rice husk ash and its use as cement replacement material," Materials Research, vol. 13, no. 2, pp. 185-190, 2010.

[14] F. Sajedi and H. A. Razak, "Effects of curing regimes and cement fineness on the compressive strength of ordinary Portland cement mortars," Construction and Building Materials, vol. 25, no. 4, pp. 2036-2045, 2011.

[15] ACI 308-92 Standard Practice for curing concrete (ACI 308-92), ACI Committee, American Concrete Institute, Farmington Hills, Mich, USA, 1998.

[16] P. S. Mangat and M. C. Limbachiya, "Effect of initial curing on chloride diffusion in concrete repair materials," Cement and Concrete Research, vol. 29, no. 9, pp. 1475-1485, 1999.

[17] V. Bonavetti, H. Donza, V. Rahhal, and E. Irassar, "Influence of initial curing on the properties of concrete containing limestone blended cement," Cement and Concrete Research, vol. 30, no. 5, pp. 703-708, 2000.

[18] J. M. Khatib and P. S. Mangat, "Influence of high-temperature and low-humidity curing on chloride penetration in blended cement concrete," Cement and Concrete Research, vol. 32, no. 11, pp. 1743-1753, 2002.

[19] N. Shafiq and J. G. Cabrera, "Effects of initial curing condition on the fluid transport properties in OPC and fly ash blended cement concrete," Cement and Concrete Composites, vol. 26, no. 4, pp. 381-387, 2004.

[20] G. Erhan, O. Juran, and G. Mehmet, "A study of reinforcement corrosion and related properties of plain and blended cement concrete under different curing conditions," Cement and Concrete Composites, vol. 27, pp. 449-461, 2005.

[21] S. K. Antiohos, V. G. Papadakis, E. Chaniotakis, and S. Tsimas, "Improving the performance of ternary blended cements by mixing different types of fly ashes," Cement and Concrete Research, vol. 37, no. 6, pp. 877-885, 2007.

[22] T. R. Naik, S. S. Singh, and M. M. Hossain, "Enhancement in mechanical properties of concrete due to blended ash," Cement and Concrete Research, vol. 26, no. 1, pp. 49-54, 1996.

[23] T.-C. Lee, W.-J. Wang, P.-Y. Shih, and K.-L. Lin, "Enhancement in early strengths of slag-cement mortars by adjusting basicity of the slag prepared from fly-ash of MSWI," Cement and Concrete Research, vol. 39, no. 8, pp. 651-658, 2009.

[24] T. Nochaiya, W. Wongkeo, and A. Chaipanich, "Utilization of fly ash with silica fume and properties of Portland cement-fly ash-silica fume concrete," Fuel, vol. 89, no. 3, pp. 768-774, 2010.

[25] Specification for 43 grade Ordinary Portland Cement, IS 8112, BIS Standards, New Delhi, India, 2013.

[26] Specification for Portland Pozzolana Cement (fly ash based), IS 1489, BIS Standards, New Delhi, India, 1991.

[27] Specification for Portland slag cement, IS 455, BIS Standards, New Delhi, India, 2015.

[28] Specification for high strength deformed steel bars and wires for concrete reinforcement, IS 1786, BIS Standard, New Delhi, India, 2008.

[29] ASTM C642 - 97, "Standard Test Method for Density, Absorption, and Voids in Hardened Concrete," in Proceedings of the ASTM International, West Conshohocken, PA, USA, 1997.

[30] V. Saraswathy and H.-W. Song, "Corrosion performance of rice husk ash blended concrete," Construction and Building Materials, vol. 21, no. 8, pp. 1779-1784, 2007.

[31] ASTM G1-03, "Standard practice for preparing, cleaning and evaluating corrosion test specimens," in Proceedings of the ASTM International, West Conshohocken, PA, USA, 2011.

[32] ASTM C1202-12, "Standard test method for electrical indication of concretes ability to resist chloride ion penetration," in Proceedings of the ASTM International, West Conshohocken, PA, USA, 2012. 
[33] H.-W. Song, V. Saraswathy, S. Muralidharan, C.-H. Lee, and $\mathrm{K}$. Thangavel, "Corrosion performance of steel in composite concrete system admixed with chloride and various alkaline nitrites," Corrosion Engineering Science and Technology, vol. 44, no. 6, pp. 408-415, 2009.

[34] ASTM G109-07, "Standard Test Method for Determining Effects of Chemical Admixtures on Corrosion of Embedded Steel Reinforcement in Concrete Exposed to Chloride Environments," in Proceedings of the ASTM International, West Conshohocken, PA, USA, 2013.

[35] V. Saraswathy, S. Muralidharan, L. Balamurugan, P. Kathirvel, and A.S. S. Sekar, "Evaluation of composite cements using cyclic polarization techniques," KSCE Journal of Civil Engineering, vol. 15, no. 8, pp. 1415-1418, 2011.

[36] M. S. Meddah and A. Tagnit-Hamou, "Pore structure of concrete with mineral admixtures and its effect on self-desiccation shrinkage," ACI Materials Journal, vol. 106, no. 3, pp. 241-250, 2009.

[37] S. P. Karthick, S. Muralidharan, V. Saraswathy, and S. Kwon, "Effect of different alkali salt additions on concrete durability property," Journal of Structural Integrity and Maintenance, vol. 1, no. 1, pp. 35-42, 2016.

[38] K. Thangavel, S. Muralidharan, V. Saraswathy, K. Y. Ann, and L. Balamurugan, "Relationship between alumina and chloride content on their physical and corrosion resistance properties of concrete," Arabian Journal for Science and Engineering, vol. 35, no. 2 A, pp. 27-38, 2010.

[39] E. Berodier and K. Scrivener, "Evolution of pore structure in blended systems," Cement and Concrete Research, vol. 73, pp. 25-35, 2015. 

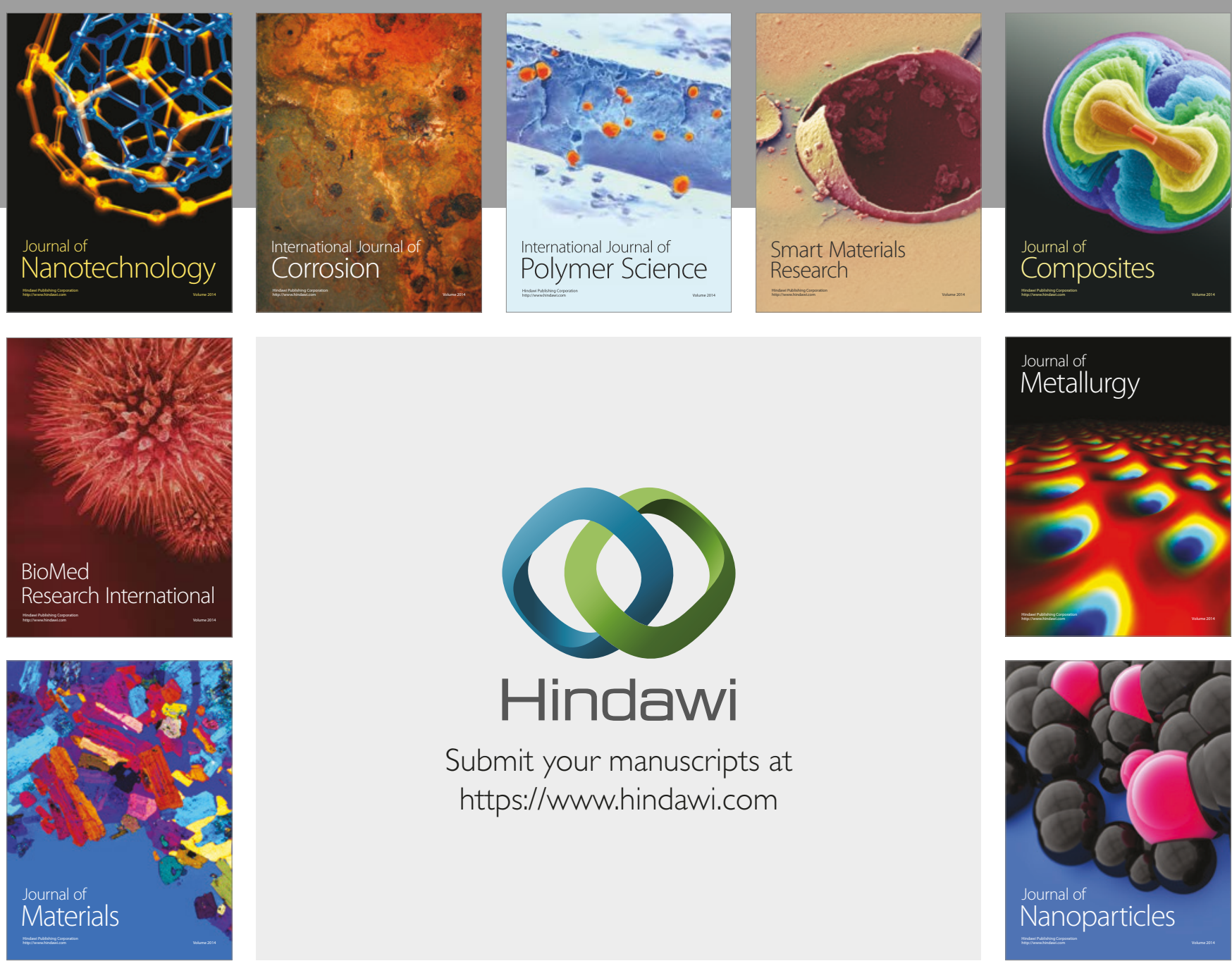

\section{Hindawi}

Submit your manuscripts at

https://www.hindawi.com
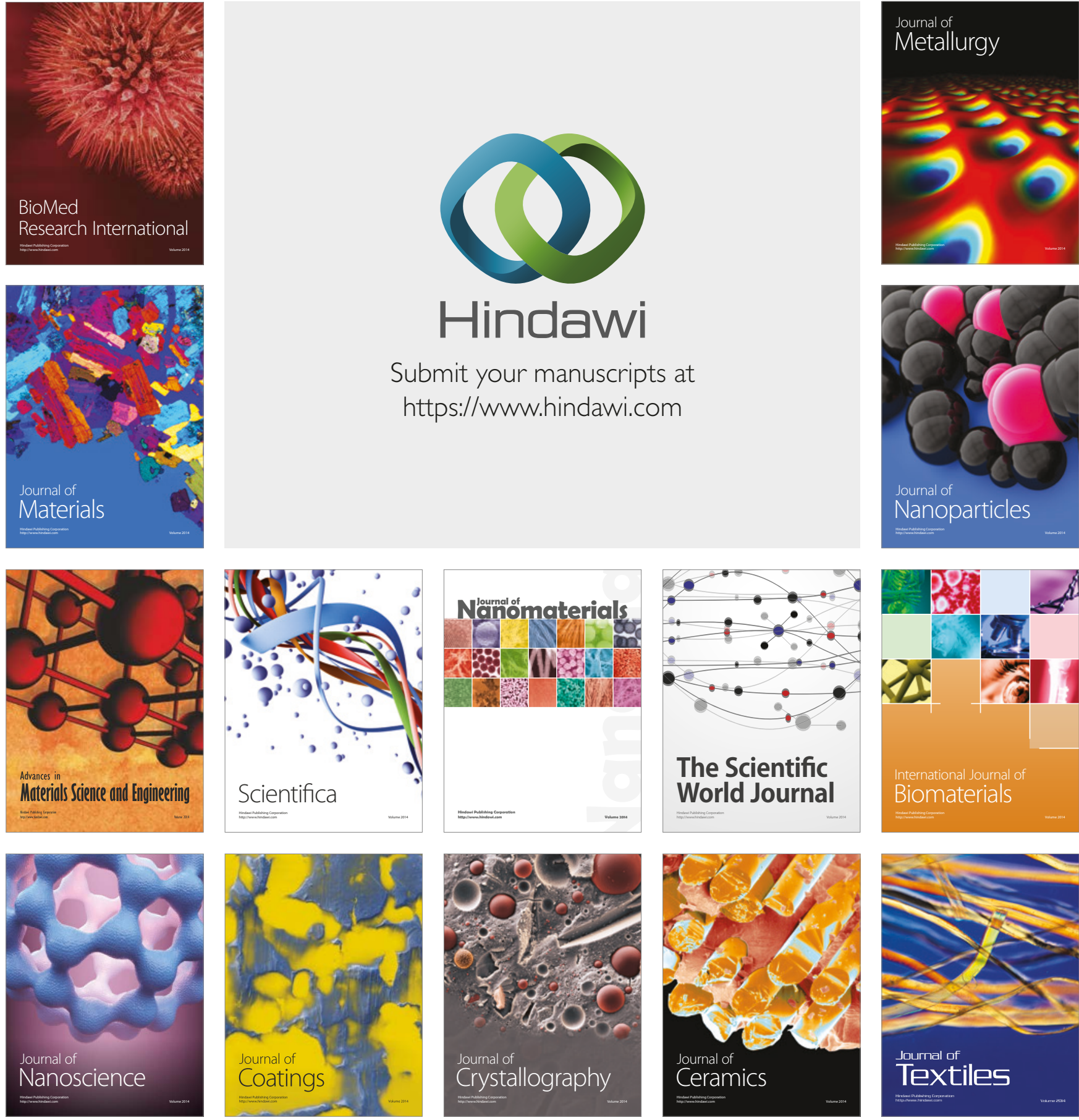

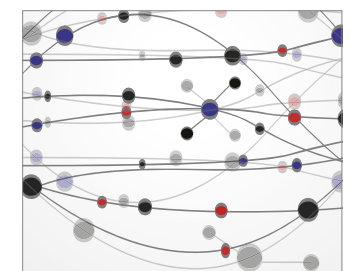

The Scientific World Journal
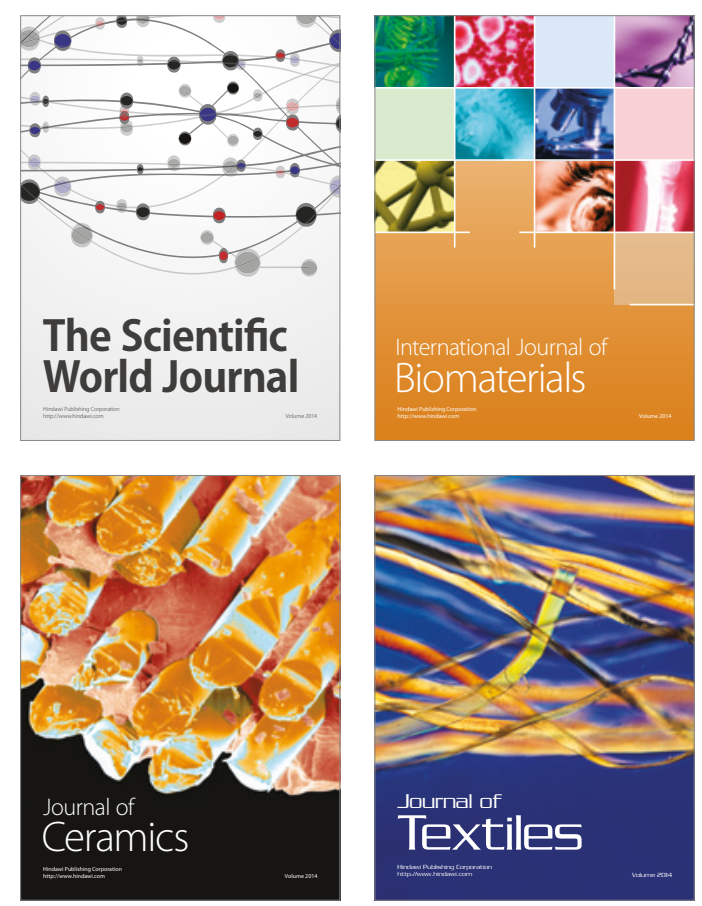